Original article

\title{
Malaria among the Sauria Paharia, a primitive and vulnerable tribe of Jharkhand state, India
}

\author{
M Rajesh Kumar Rao ${ }^{*}, 1$, Manoj Kumar Das ${ }^{1}$ \\ ICMR-National Institute of Malaria Research, Field Unit, ITKI, Ranchi, Jharkhand, India
}

\section{A R T I C L E I N F O}

\section{Keywords:}

Sauria Paharia

Vulnerable tribal groups (PTGs)

Forest-fringed villages

Malaria

Anophelines

Knowledge

Attitudes, and practices (KAP)

ASHA worker

Early diagnosis and prompt treatment (EDPT)

Pakur district

\begin{abstract}
A B S T R A C T
Background: Pakur district of Jharkhand state is highly malaria-endemic areas in eastern India, mainly inhabited by Sauria Paharia, a primitive and vulnerable tribal group.

Methods: An epidemiological, entomological and malaria-related community-based education; and evaluation of the operational strategies for malaria interventions were performed in eight vulnerable forests-fringed tribal villages in the Pakur district of Jharkhand, India.

Results: Of the 217 confirmed malaria infections, P. falciparum (92.2\%), P. vivax (7.8\%), and mixed-species infections (6.9\%) were found. The SPR, SFR and Pf\% ranged from 23.8 to 68.2, 23.8-64.8 and 84.2-100.0, respectively. An. culicifacies, An. annularis, An. fluviatilis and An. minimus became the primary vectors of malaria. Insecticidal susceptibility status indicates An. culicifacies and An. annularis resistance to DDT (4\%); and An. culicifacies, An. annularis and An. fluviatilis susceptible to malathion (5\%) and deltamethrin (0.05\%). Most residents, including health staff, had excellent knowledge of malaria but did not adopt appropriate prevention steps. Many accredited social health activist workers have not trained to diagnose and treat malaria cases, nor have rapid diagnostic test kits and antimalarial drugs been available, resulting in the tribal community adopting traditional treatments and native remedies.

Conclusion: High vector abundance, presence of parasite load, deficiency of prevention practices; and lack of early detection and prompt treatment and vector control strategies indicate that the population living in these provinces is more vulnerable to malaria. Therefore, periodic surveillance, monitoring, and evaluation are also needed to enhance the implementation of malaria interventions in this region.
\end{abstract}

\section{Introduction}

Malaria remains one of the most serious vector-borne diseases in India triggered by a Plasmodium parasite that infects humans by certain species of Anopheline mosquitoes, resulting in 0.7-1.6 million cases and 400-1,000 deaths annually. ${ }^{1,2}$ There are more than 58 distinct species of the Anopheles genus and about six species, including the siblings implicated as the most potent malaria vectors with widespread distribution throughout the year in India. ${ }^{3}$ Transmission intensity depends on the correlation between the epidemiological risk factors related to the parasite, the vector, the human host and the environment. ${ }^{4}$ Despite the adept antimalarial and integrated vector management (IVM) strategies in the National Vector-Borne Diseases Control Programme (NVBDCP), malaria transmission remains uninterrupted. Malaria is becoming more diversified through the pressure on the development of distinct ecotypes, i.e. urban malaria, industrial malaria, rural malaria, forest malaria, border malaria and malaria migration. ${ }^{5}$ In India, tribal communities and vulnerable tribal groups (PTGs) (Identified as the Primitive Tribal Groups) live in inaccessible forests, hills, valleys, and perennial streams. This topography and environmental potential for vector growth and the proliferation of parasite is susceptible to the human population that has resulted in a strong transmission of malaria. ${ }^{6}$ In particular, PTGs are the most isolated and autochthonous people on land with a noticeable decline in their population live in an unpolluted region far from civilization. ${ }^{7}$ Malaria, including other mosquito-borne diseases, is rampant in PTG provinces and exposure to social welfare programmes for these communities remains limited. ${ }^{8}$ In India, 75 PTGs in 17 states and one Union Territory (UT) are living in high malaria transmission areas. Jharkhand state in the eastern region of India contributes $6.8 \%$ of PTGs to the overall population of PTGs living in India and is considered

\footnotetext{
* Corresponding author.

E-mail addresses: raomrajeshkumar@gmail.com (M.R.K. Rao), manojdas2@gmail.com (M.K. Das).

1 Equal contribution.
} 


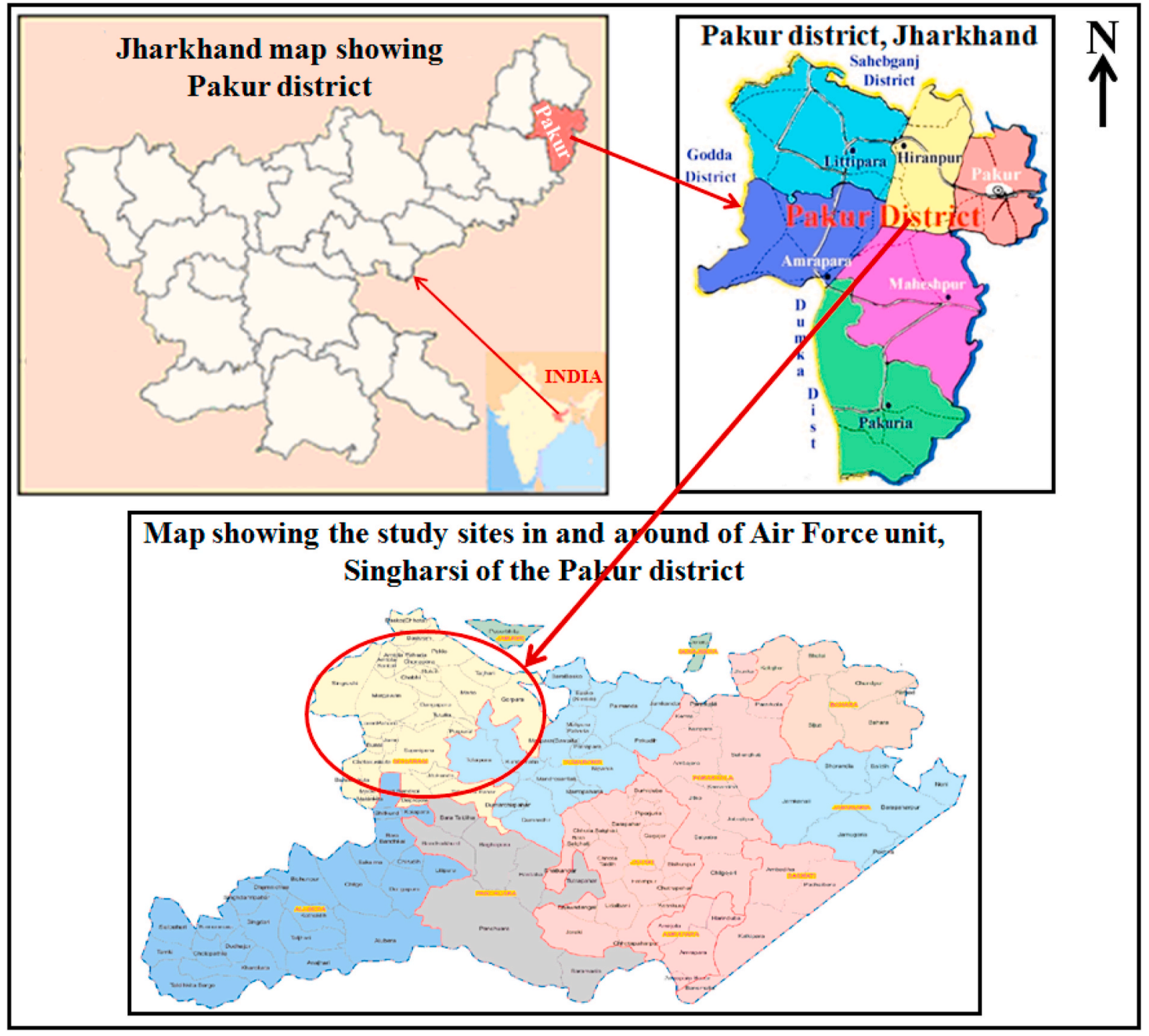

Fig. 1. Map showing the study areas in and around of air force (AF) unit, Singharsi of the Pakur district in Jharkhand, India.

as one of the hot spots for malaria infection. ${ }^{9}$ According to the census 2011, about 2.23 lakhs of PTG population of Jharkhand were living in the eleven districts, including Ranchi, Lohardaga, Gumla, West Singhbhum, Dumka, Pakur, Hazaribagh, Palamu, Garhwa, Dhanbad, and Giridih.

The Pakur district of Jharkhand contributes $0.7 \%$ of the total malaria cases in India and is one of the endemic places where malaria has reported the number of deaths every year. The annual slide positivity rate (SPR) and the slide falciparum rate (SFR) of the district of Pakur were 3.6 and 2.9, respectively; and the incidence of $P$. falciparum was $82.6 \%{ }^{10}$ In the socio-economic conditions of the last year, climate change and deforestation have produced mosquitogenic conditions and perpetual malaria transmission in the region. ${ }^{11}$ There is little information available on the incidence of malaria, as well as the distribution and composition of vector mosquitoes in the region, due to limited epidemiological and entomological studies conducted in different parts of the state, rendering any malaria control strategy difficult to implement. Hence, the high incidence of malaria is deleterious and the failure of control strategies poses a life-threatening disease, contributing to an overtime decline in the populations of the isolated and autochthonous PTG communities living in the region.

A request was made by the Directorate General of Medical Services (Air Force) DMS (H), New Delhi, to carry out entomological and epidemiological studies on malaria in and around the Sigharsi Air Force Station in the Pakur district and to provide remedial measures to control malaria. Therefore, the epidemiological, entomological and educational diagnosis of malaria in inaccessible, forest-ridden tribal villages in and around Singharsi, Pakur district, was undertaken to study the incidence of malaria cases and to elucidate the knowledge and prevention strategies and operational challenges faced by the community in the fight against malaria.

\section{Materials and methods}

\subsection{Study site}

The district of Pakur, situated in the north-east corner of Jharkhand State in eastern India, lies between $23^{\circ} 40^{\prime} \mathrm{N}$ and $25^{\circ} 18^{\prime} \mathrm{N}$ and $86^{\circ} 25^{\prime} \mathrm{E}$ and $87^{\circ} 57^{\prime} \mathrm{E}$. The geographical area of the district of Pakur is 1806 sq. $\mathrm{km}$. In the 2011 Indian census, the district of Pakur had a population of 900,422 of which 452,661 were male and 447,761 were female. The district of Pakur was the land of the Santhal tribes, the Mal Paharia PTGs and the Sauria Paharia PTGs had a population of 379,054 . With a brief winter, the climate of the district is subtropical, with temperatures ranging from 4 to $44{ }^{\circ} \mathrm{C}$ (see Fig. 1). The study area comprises eight villages, Rakha, Paktadi, Balmi, Madgama, Mamamod, Singarsi, 
Table 1

Result of active surveillance of malaria in the eight villages in and around AF unit, Singharsi of the Pakur district, Jharkhand.

\begin{tabular}{|c|c|c|c|c|c|c|c|c|}
\hline Village & $\mathrm{BSC} / \mathrm{E}$ & Malaria +ve & $P v$ & $P f$ & Mix & $S P R$ & $S F R$ & $P f \%$ \\
\hline Rakha & 47 & 25 & 0 & 24 & 1 & 53.2 & 53.2 & 100.0 \\
\hline Paktadi & 94 & 52 & 5 & 41 & 6 & 55.3 & 50.0 & 90.4 \\
\hline Balmi & 21 & 8 & 1 & 6 & 1 & 38.1 & 33.3 & 87.5 \\
\hline Madgama & 21 & 5 & 0 & 4 & 1 & 23.8 & 23.8 & 100.0 \\
\hline Mamamod & 42 & 25 & 2 & 21 & 2 & 59.5 & 54.8 & 92.0 \\
\hline Singarsi & 88 & 60 & 3 & 54 & 3 & 68.2 & 64.8 & 95.0 \\
\hline DumDum & 66 & 23 & 3 & 19 & 1 & 34.8 & 30.3 & 87.0 \\
\hline Chabli & 51 & 19 & 3 & 16 & 0 & 37.3 & 31.4 & 84.2 \\
\hline Total & 430 & 217 & 17 & 185 & 15 & 50.5 & 46.5 & 92.2 \\
\hline Mean & 53.8 & 27.1 & 2.1 & 23.1 & 1.9 & 46.3 & 42.7 & 92.0 \\
\hline
\end{tabular}

$*$ BSC/E = Blood slides collected/examined; $P v=$ Plasmodium vivax; Pf = Plasmodium falciparum; SPR = Slide positivity rate; SFR = Slide falciparum rate.

DumDum, and Chabli in and around 507 SU, air force (AF) unit, Singharsi of the Pakur district, Jharkhand. The villages are forest-fringed and scattered. Forest terrain and perennial streams/nallahs (locally called) maintain a moderate climate that favors rapid growth and longevity of malaria vectors throughout the year. The socio-economic status of the villagers is poor and the people depend on forest products and paddy cultivation.

\subsection{Study populations}

The study was carried out on human population of all age groups living in the eight forest-fringed villages in and around of Singharsi of the Pakur district, Jharkhand, belonging to Sauria Paharia vulnerable tribal groups (PTGs).

\subsection{Study period}

The research study was undertaken during the rainy or monsoon period from August to September 2015 in order to achieve the objectives.

\subsection{Epidemiological investigation}

House to house malaria active case detection (ACD) of the symptomatic fever cases was carried out in eight villages in and around 507 SU, AF unit, Singharsi of the Pakur district, Jharkhand. Finger prick blood samples were obtained and used to prepare the peripheral blood smears (thick and thin) were made of clean slides and labeled as recommended by the World Health Organization. Thin films were fixed with methanol and stained with $3 \%$ Giemsa stain of pH 7.0 for 30 min. Stained slides were examined under the light microscope using the $\mathrm{X}$ 100 objective lens with immersion oil for the detection of malaria. All positive cases of malaria have been administered with antimalarial drugs as per the National Drug Policy. ${ }^{12}$

\subsection{Entomological investigation}

\subsubsection{Larval survey}

Larval surveys were carried out in different water sources, including irrigation canals, riverbeds, lake, ponds, streams and water collected near the pumps scattered along with the villages. Water sources inside and outside houses, such as storage ponds, concrete lakes, and reservoirs, have also been studied and recorded. Larval sampling was done using a standardized dipper $(300 \mathrm{ml})$ dip method. The larvae have been identified according to the appropriate keys. ${ }^{13}$

\subsubsection{Adult mosquito survey}

Two methods were used for adult mosquitoes collected during this study. Those are the hand collection of indoor resting mosquitoes and the Center for Disease Control Light Trap (CDC-LT).
2.5.2.1. Hand collection of indoor resting mosquitoes. Adult mosquitoes' were collected during morning hours between 05:00 a.m. to 07:00 a.m. from human dwellings (HD) and cattle sheds (CS) using the hand collection method with a mouth aspirator. The mosquitoes were anesthetized with ether and identified as per the appropriate keys. ${ }^{14}$ Adult densities of each species of mosquitoes were calculated was calculated using the following formula:

\begin{tabular}{lll}
\hline Adult densities $=$ & $\begin{array}{l}\text { Total no. of mosquitoes collected } \\
\text { No. of the person involved }\end{array}$ & X Time spent in hours \\
\hline
\end{tabular}

2.5.2.2. Center for disease control light trap (CDC-LT). Light traps (one in each village) were placed in each house identified and operated from 6.00 p.m. to 6.00 a.m. Mosquitoes were attracted to the ultraviolet light at night and trapped into a funnel mesh screen attached in the light trap. The mosquitoes were anesthetized with ether and identified as per the appropriate keys. ${ }^{14}$

\subsubsection{Adult mosquito bioassay}

Bioassay of insecticidal tolerance for mosquito vectors was carried out using WHO susceptibility tests. ${ }^{15}$ Three different insecticide-treated filter papers at the WHO discriminating concentrations were used. ${ }^{16}$ These were DDT 4.0\%, Malathion 5.0\%, and Deltamethrin 0.05\%. The exposure period was $1 \mathrm{~h}$ at the diagnostic dose. Following exposure, mosquitoes were transferred back into the insectary and then provided with cotton pads soaked in $10 \%$ sugar solution and the mortality was recorded after $24 \mathrm{~h}$.

\subsection{Educational diagnosis of the community about malaria}

\subsubsection{Interviews of ASHAs' and others regarding malaria-related knowledge and prevention practices}

An interviewer-administered survey was carried out to assess the malaria-related knowledge and prevention practices from various levels of respondents, including Accredited Social Health Activist (ASHA) locally called 'Sahiyya', and Male/Female MPHWs are the community member of healthcare workers; and village leaders and household respondents using a structured questionnaire.

\subsubsection{Interviews of ASHAs' regarding their ability in malaria diagnosis and treatment}

ASHA's were interviewed using a structured questionnaire regarding their ability to detect malaria (preparation of blood test and usage of RDT kit) and to control malaria by providing antimalarial drugs in compliance with the National Drug Policy. ${ }^{12}$

\subsubsection{Community perception of ASHAs' treatment for malaria and relief}

Individual household respondents were interviewed using a structured questionnaire on the availability of ASHA in their village, their visit to ASHA for malaria treatment and treatment satisfaction. 
Table 2

Larval survey and the breeding habitats of immature Anopheline species in the eight villages in and around AF unit, Singharsi of the Pakur district, Jharkhand.

\begin{tabular}{|c|c|c|}
\hline $\begin{array}{l}\text { Breeding } \\
\text { habitat }\end{array}$ & $\begin{array}{l}\text { Type of } \\
\text { habitat }\end{array}$ & Types of mosquito species emerge from larvae \\
\hline Ponds & Natural BH & $\begin{array}{l}\text { An. culicifacies, An. annularis, An. subpictus, An. } \\
\text { vagus, and An. splendidus. }\end{array}$ \\
\hline Streams & Natural BH & An. culicifacies and An. fluviatilis. \\
\hline Riverbeds & Natural BH & $\begin{array}{l}\text { An. culicifacies, An. annularis, An. splendidus, and } \\
\text { An. theobaldi }\end{array}$ \\
\hline Tree holes & Natural BH & An. culicifacies \\
\hline Unused well & Natural BH & $\begin{array}{l}\text { An. culicifacies, An. annularis,An. subpictus, An. } \\
\text { vagus, An. fluviatilis and An. barbirostris }\end{array}$ \\
\hline Others & Discards BH & $\begin{array}{l}\text { An. culicifacies, An. annularis, An. subpictus, An. } \\
\text { vagus, An. fluviatilis, An. barbirostris, An. minimus } \\
\text { and An. maculatus }\end{array}$ \\
\hline
\end{tabular}

\subsection{Statistical analysis}

Microsoft Excel-2007 was used for the analysis of the statistical values. Percentage (\%) and the mean value were used in this study. Epidemiological parameters such as SPR, SFR, PF\%, and age and sexwise distribution of malaria cases were analyzed. Entomological parameters such as larval density, adult density and corrected mortality (\%) of anopheline species were analyzed.

\section{Result}

\subsection{Epidemiological investigation of malaria}

The result of the active surveillance of malaria was carried out in eight forest-fringed villages in and around the AF unit, Singharsi of the Pakur district, Jharkhand (Table 1). All the populations living in these eight villages belong to the vulnerable tribal group of Sauria Paharia. As a result, a total of 430 blood samples and slides were collected and examined. Of these, 217 cases were reported to be positive for malaria parasites. $P$. falciparum infection was the most abundant and accounted for $92.2 \%$ of the total cases. The least prevalent cases were identified as $P$. vivax $(17,7.8 \%)$ and 15 cases of mixed-species malaria infection were identified among the total cases. Two percent of $P$. falciparum cases were identified with the parasite stage of the gametocyte in the peripheral blood smear. SPR, SFR, and Pf\% ranged from 23.8 to $68.2,23.8-64.8$ and 84.2-100.0, respectively; and the mean values of the SPR, SFR and $P f \%$ were $46.3,42.7$ and 92.0, respectively. The highest $S P R$ was observed in Singharsi (68.2\%) and the lowest in Madgama (23.8\%). The highest percentages of asymptomatic carriers of $P f(20 \%)$ have been detected in populations without any symptoms during active malaria surveillance. All positive malaria cases have been treated in accordance with the National Drug Policy.

\subsection{Entomological investigation of malaria vectors}

Larval survey and breeding habitats of immature Anopheline species in eight forest-fringed villages in and around the AF unit, Singharsi was shown in Table 2. The results revealed that mosquito larvae were found in both natural and discarded breeding habitats in the study areas. During the larval survey, 20 species of mosquitoes in five genera (Anopheles, Aedes, Armigeres, Culex, and Mansonia) were identified as per the standard keys of Christopher, Barraud, Puri, Wattal and Karla; and Nagpal and Sharma. ${ }^{17-21}$ Of these, 10 species of immature Anophelines (An. culicifacies, An. fluviatilis, An. annularis, An. minimus, An. theobaldi, An. vagus, An. subpictus, An. splendidus, An. barbirostris, and An. maculatus) was collected from different breeding habitats. On the basis of their emergence, An. culicifacies have been observed in all breeding habitats (ponds, streams, riverbed pools, and unused wells), An. annularis, An. subpictus, An. vagus, and An. splendidus has been identified in ponds; and An. fluviatilis was found in streams and unused wells. However, An. theobaldi was observed only in the riverbeds.

Table 3 presents the relative abundance and resting preferences of the adult Anopheline species. The results revealed that 803 adult mosquitoes belonging to 10 species of the Anopheles genus were collected. Of the adult Anopheline species, An. culicifacies ( $\mathrm{n}=320$, $39.9 \%$ ) was the most abundant malaria vector in countering malaria followed by those An. annularis $(\mathrm{n}=58,7.2 \%)$ and An. fluviatilis $(\mathrm{n}=12$, $1.5 \%)$. The resting preference of adult Anopheline species was found more in cattle sheds $(\mathrm{n}=460,57.3 \%)$ than in human dwellings $(\mathrm{n}=$ 343, 42.7\%) after feeding to the host. Adult Anopheline species captured using CDC light trap showed that, An. culicifacies was the most dominant species followed by those An. fluviatilis and An. annularis.

Table 3

Species relative abundance and resting preferences for the adult Anopheline species in the eight villages in and around AF unit, Singharsi of the Pakur district, Jharkhand.

\begin{tabular}{|c|c|c|c|c|c|c|c|c|}
\hline \multirow[t]{3}{*}{ Species } & \multicolumn{2}{|c|}{ Species relative abundance } & \multicolumn{6}{|c|}{ Resting preferences } \\
\hline & \multirow[t]{2}{*}{$\mathrm{TMC}^{*}$} & \multirow[t]{2}{*}{ Abundance (\%) } & \multicolumn{2}{|l|}{ HD } & \multicolumn{2}{|l|}{$\mathrm{CS}$} & \multicolumn{2}{|l|}{ Total } \\
\hline & & & No & $\%$ & No & $\%$ & No & $\%$ \\
\hline An. culicifacies & 320 & 39.9 & $\begin{array}{l}134 \\
(39.1)\end{array}$ & 16.7 & $\begin{array}{l}186 \\
(40.4)\end{array}$ & 23.2 & 320 & 39.9 \\
\hline An. fluviatilis & 12 & 1.5 & $\begin{array}{l}11 \\
(3.2)\end{array}$ & 1.4 & $\begin{array}{l}1 \\
(0.2)\end{array}$ & 0.1 & 12 & 1.5 \\
\hline An. annularis & 58 & 7.2 & $\begin{array}{l}5 \\
(1.5)\end{array}$ & 0.6 & $\begin{array}{l}53 \\
(11.5)\end{array}$ & 6.6 & 58 & 7.2 \\
\hline An. splendidus & 11 & 1.4 & $\begin{array}{l}0 \\
(0.0)\end{array}$ & 0.0 & $\begin{array}{l}11 \\
(2.4)\end{array}$ & 1.4 & 11 & 1.4 \\
\hline An. theobaldi & 6 & 0.7 & $\begin{array}{l}1 \\
(0.3)\end{array}$ & 0.1 & $\begin{array}{l}5 \\
(1.1)\end{array}$ & 0.6 & 6 & 0.7 \\
\hline An. maculatus & 3 & 0.4 & $\begin{array}{l}0 \\
(0.0)\end{array}$ & 0.0 & $\begin{array}{l}3 \\
(0.7)\end{array}$ & 0.4 & 3 & 0.4 \\
\hline An. minimus & 2 & 0.2 & $\begin{array}{l}1 \\
(0.3)\end{array}$ & 0.1 & $\begin{array}{l}1 \\
(0.2)\end{array}$ & 0.1 & 2 & 0.2 \\
\hline An. vagus & 329 & 41.0 & $\begin{array}{l}168 \\
(49.0)\end{array}$ & 20.9 & $\begin{array}{l}161 \\
(35.0)\end{array}$ & 20.0 & 329 & 41.0 \\
\hline An. subpictus & 50 & 6.2 & $\begin{array}{l}17 \\
(5.0)\end{array}$ & 2.1 & $\begin{array}{l}33 \\
(7.2)\end{array}$ & 4.1 & 50 & 6.2 \\
\hline An. barbirostris & 12 & 1.5 & $\begin{array}{l}6 \\
(1.7)\end{array}$ & 0.7 & $\begin{array}{l}6 \\
(1.3)\end{array}$ & 0.7 & 12 & 1.5 \\
\hline Total & 803 & 100.0 & 343 & 42.7 & 460 & 57.3 & 803 & 100 \\
\hline
\end{tabular}

* TMC $=$ Total number of adult mosquito collected, HD = Human dwellings, CS = Cattle sheds. 


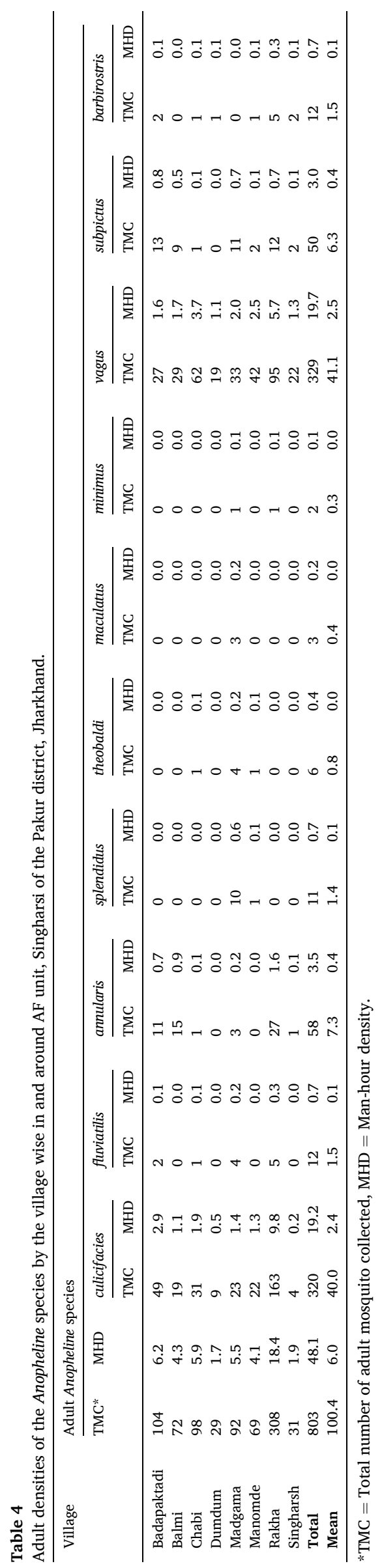

The adult density of the Anopheline species was presented by the village wise (Table 4). As a result, the adult density of the Anopheline species ranged from 1.7 to 18.4 and the mean adult density of the Anopheline species was 6.0. The highest adult density of the Anopheline species was observed in the village of Rakha (18.4) followed by Badapaktadi (6.2), while the lowest adult density of the Anopheline species was observed in the village of Dumdum (1.7). An. culicifacies had the highest adult density (19.2) compared to the other Anopheline species that were collected from the eight villages.

An. culicifacies An. annularis and An. fluviatilis were the important malaria vectors in countering malaria in the eight villages in and around AF unit, Singharsi of the Pakur district, Jharkhand. These three malaria vectors were exposed to impregnated papers as WHO recommended the discriminating concentrations ( $\mathrm{v} / \mathrm{w})$ of DDT (4.0\%), Malathion (5.0\%), and Deltamethrin $(0.05 \%)$. The result of the susceptibility status of malaria vectors to insecticides has shown that, An. Culicifacies ( $5 \%$ mortality rate) and An. Annularis (15\% mortality rate) has been shown to have $100 \%$ DDT resistance but is susceptible to Malathion (95\% and $100 \%$ mortality rate) and Deltamethrin ( $95 \%$ and $100 \%$ mortality rate). However, An. fluviatailis (mortality rate range of 95-100\%) was susceptible to all three of these insecticides (Table 5).

\subsection{Knowledge of the community and health workers on malaria}

\subsubsection{Socio-demographic characteristics of the interviewed respondents}

Table 6 presents the demographic distributions of the respondents interviewed in the study $(\mathrm{N}=184)$. Of these, there were $117(63.5 \%)$ males and 67 (36.5\%) females. Maximum respondents (35.6\%) belonged to age groups $31-40$ years of age and education-wise, $26.9 \%$ of participants studied up to matric, followed by those up to the primary standard (26.0\%); however, $15.4 \%$ of participants were illiterate. The largest proportions (33.7\%) of respondents were agriculturists followed by daily wage workers $(26.9 \%)$ and Government or private service (22.1\%).

\subsubsection{Malaria-related knowledge of the interviewed respondents}

Malaria-related knowledge, transmission, and prevention practice of respondents were presented on the basis of their responses to our questionnaire (Table 7). Overall, $97.8 \%$ of respondents had heard of malaria, but there were variations in awareness of malaria symptoms, transmission and preventive strategies among respondents. $93.5 \%$ of respondents had reported that fever was the most common symptom of malaria. Other symptoms such as chill, headache, vomiting, sweating, and body pain were reported less frequently than the most common symptoms reported by $86.4 \%, 77.2 \%, 60.3 \%, 56.0 \%$ and $35.9 \%$ of respondents, respectively. Based on malaria transmission, the maximum proportion of respondents $(80.4 \%)$ identified the highest risk of malaria during the rainy season. $84.2 \%$ of respondents were aware that malaria transmission occurred due to the bite of the infected mosquito. However, $10.3 \%$ of respondents were misconceptions that malaria may be transmitted through close contact with malaria patients, drinking contaminated water and eating contaminated food. $92.4 \%$ of respondents were aware that nighttime is the time to bite mosquitoes that transmit malaria.

Most of those respondents were conscious that the dark corners of the house $(91.3 \%)$ and the domestic animal shelters $(87.0 \%)$ were the preferred place of rest for mosquitoes. $95.1 \%$ of respondents were aware that mosquitoes are preferred to breed in a pond or canal or stagnant water. Regarding the malaria precautionary practice, $34.8 \%$ of respondents have removed the stagnant water near the house, followed by using mosquito repellent/coil (33.7\%), indoor residual spray (33.2\%), clean dark corner of the house (32.6\%) and using insecticide-treated bed nets $(28.3 \%)$. 
Table 5

Susceptibility status of malaria vectors to various insecticides.

\begin{tabular}{|c|c|c|c|c|c|c|c|}
\hline \multirow[t]{2}{*}{ Malaria vectors } & \multirow[t]{2}{*}{ Insecticide papers used in $\%$ conc. } & \multicolumn{2}{|c|}{ No. of mosquitoes exposed } & \multicolumn{2}{|c|}{ No. of mosquitoes deed } & \multirow[t]{2}{*}{ Corrected \% mortality } & \multirow[t]{2}{*}{ Susceptibility status } \\
\hline & & Test & Control & Test & Control & & \\
\hline \multirow[t]{3}{*}{ An. culicifacies } & DDT (4.0\%) & 20 & 20 & 0 & 1 & 5 & $\mathrm{R}^{\mathrm{a}}$ \\
\hline & Malathion (5\%) & 20 & 20 & 0 & 19 & 95 & $\mathrm{~S}^{\mathrm{a}}$ \\
\hline & Deltamethrin $(0.05 \%)$ & 20 & 20 & 0 & 19 & 95 & $\mathrm{~S}^{\mathrm{a}}$ \\
\hline \multirow[t]{3}{*}{ An. annularis } & DDT $(4.0 \%)$ & 20 & 20 & 0 & 3 & 15 & $\mathrm{R}^{\mathrm{a}}$ \\
\hline & Malathion (5\%) & 20 & 20 & 0 & 20 & 100 & $\mathrm{~S}^{\mathrm{a}}$ \\
\hline & Deltamethrin $(0.05 \%)$ & 20 & 20 & 0 & 20 & 100 & $S^{a}$ \\
\hline \multirow[t]{3}{*}{ An. fluviatailis } & DDT $(4.0 \%)$ & 20 & 20 & 0 & 19 & 95 & $\mathrm{~S}^{\mathrm{a}}$ \\
\hline & Malathion (5\%) & 20 & 20 & 0 & 20 & 100 & $\mathrm{~S}^{\mathrm{a}}$ \\
\hline & Deltamethrin $(0.05 \%)$ & 20 & 20 & 0 & 20 & 100 & $S^{a}$ \\
\hline
\end{tabular}

${ }^{\mathrm{a}} \mathrm{R}=$ Resistant, $\mathrm{S}=$ susceptible.

Table 6

Socio-demographic characteristics of the interviewed respondents in the eight villages in and around AF unit, Singharsi of the Pakur district, Jharkhand.

\begin{tabular}{|c|c|c|c|c|c|}
\hline \multirow[t]{2}{*}{ Parameters } & \multicolumn{5}{|c|}{ Respondents interviewed } \\
\hline & Sahiyya $* 0(\mathrm{~N}=8)$ & MPHWs \% $(\mathrm{N}=8)$ & Village leaders \% $(\mathrm{N}=8)$ & Individuals ${ }^{\#} \%(\mathrm{~N}=160)$ & Total $\%(\mathrm{~N}=184)$ \\
\hline \multicolumn{6}{|l|}{ Gender } \\
\hline Male & 0.0 & 100.0 & 100.0 & 62.5 & 63.5 \\
\hline Female & 100.0 & 0.0 & 0.0 & 37.5 & 36.5 \\
\hline \multicolumn{6}{|l|}{ Age } \\
\hline $18-30$ & 25.0 & 12.5 & 0 & 25 & 22.1 \\
\hline $31-40$ & 75.0 & 62.5 & 12.5 & 31.3 & 35.6 \\
\hline $41-50$ & 0.0 & 25.0 & 62.5 & 22.5 & 24.0 \\
\hline$>50$ & 0.0 & 0.0 & 25.0 & 21.2 & 18.3 \\
\hline \multicolumn{6}{|l|}{ Literacy } \\
\hline Illeterate & 0.0 & 0.0 & 0.0 & 20.0 & 15.4 \\
\hline Up to Primary & 0.0 & 0.0 & 12.5 & 32.5 & 26.0 \\
\hline Up to middle & 0.0 & 25.0 & 25.0 & 26.2 & 24.0 \\
\hline Up to matric & 75.0 & 75.0 & 37.5 & 16.3 & 26.9 \\
\hline Above matric & 25.0 & 0.0 & 25.0 & 5.0 & 7.7 \\
\hline \multicolumn{6}{|l|}{ Occuption } \\
\hline Service (Government/Private) & 100.0 & 100.0 & 37.5 & 5.0 & 22.2 \\
\hline Business person & 0.0 & 0.0 & 25.0 & 6.2 & 6.7 \\
\hline Agriculture & 0.0 & 0.0 & 37.5 & 40 & 33.7 \\
\hline Daily wage worker & 0.0 & 0.0 & 0.0 & 35 & 26.9 \\
\hline Housewife & 0.0 & 0.0 & 0.0 & 8.8 & 6.7 \\
\hline Student & 0.0 & 0.0 & 0.0 & 5.0 & 3.8 \\
\hline
\end{tabular}

*ASHA locally called 'Sahiyya', \# Individual household respondents.

\subsubsection{Malaria diagnosis and treatment-related knowledge of the} interviewed ASHA workers and community perception on ASHA workers' ability in treatment for malaria and relief

Table 8 presents the operational abilities of the malaria diagnosis and treatment of ASHA workers and the community perception of ASHA treatment for malaria and relief. As a result, eight ASHA workers (one in each village) were available in eight villages for early diagnosis and prompt treatment (EDPT) of malaria cases.

Of these, $62.5 \%$ of ASHA workers were trained in the method of diagnosing malaria using RDT and blood smear preparation. $50.0 \%$ of ASHA workers have known the age-class dosages schedule for antimalarial drugs and treating malaria cases. Among the eight villages, the number of individual household respondents who visited ASHA workers for malaria treatment ranged from 19.0 to 85.7 . The stock of the RDT kit for malaria diagnosing was available to ASHA workers in four villages, but only one ASHA worker had anti-malarial drugs available. Among the households visited by ASHAs, $16.7 \%$ of households were satisfied with the ability of ASHA workers to treat malaria.

\section{Discussion}

Malaria is one of Jharkhand's serious public health problems. Large proportions of vulnerable tribal communities live in isolated, inaccessible, hilly, forest-fringed villages and hamlets that sustain malaria transmission all year round in Jharkhand. ${ }^{22,23}$ In order to understand the profile of malaria, the dynamics of malaria transmission and the magnitude of the tribal malaria problem that would help in the introduction of new malaria prevention intervention strategies, this study was carried out in the eight forest-fringed tribal villages in and around AF unit, Singharsi of the Pakur district of Jharkhand state in eastern India and its inhabitants were the vulnerable tribal community of Shari Paharia.

Our study showed that $P$. falciparum was significantly higher than $P$. vivax in all cases of Plasmodium infections. In overall cases, a higher proportion of $P$. falciparum infection (92.2\%) was found. 6.9\% of cases of mixed-species malaria infection have been found in all cases. The highest percentages of $P f$ asymptomatic carriers have been identified in the population that has no symptoms during active malaria surveillance. Therefore, these asymptomatic cases act as a reservoir for the transmission of cases to a healthier person by vectors. All positive $P f$ cases and mixed-species malaria infections were treated with Artemisinin-based combination therapy (Artesunate+Sulfadoxine-Pyrimethamine) for 3 days and Primaquine $0.25 \mathrm{mg}$ per $\mathrm{kg}$ bodyweight daily for 14 days, contributing to rapid contraction of the malaria parasite reservoir in the community. ${ }^{12}$ Our study corroborates the prevalence of higher-altitude malaria in these tribal areas, consistent with the earlier observations made in the Rajmahal range of Jharkhand (earlier in Bihar), the Tirap district of Arunachal Pradesh, the Sonitpur district of Assam, and the Sundargarh and Koraput districts of Odisha. ${ }^{24-28}$

In this study, immature Anopheline species were found in ponds, streams, riverbeds, tree holes, unused wells, and other discard breeding habitats. The development of the larval population is due to the 
Table 7

Malaria-related knowledge, transmission, and prevention practice of the interviewed respondents in the eight villages in and around AF unit, Singharsi of the Pakur district, Jharkhand.

\begin{tabular}{|c|c|c|c|c|c|}
\hline \multirow[t]{2}{*}{ Parameters } & \multicolumn{5}{|c|}{ Respondents interviewed } \\
\hline & $\begin{array}{l}\text { Sahiyya }{ }^{\mathrm{a}} \\
\%(\mathrm{~N}=8)\end{array}$ & $\begin{array}{l}\mathrm{MPHW}^{\mathrm{b}} \\
\%(\mathrm{~N}= \\
8)\end{array}$ & $\begin{array}{l}\text { Village } \\
\text { leaders } \\
\%(\mathrm{~N}= \\
8)\end{array}$ & $\begin{array}{l}\text { Individuals }{ }^{\mathrm{c}} \\
\%(\mathrm{~N}=160)\end{array}$ & $\begin{array}{l}\text { Total } \\
\%(\mathrm{~N} \\
= \\
184)\end{array}$ \\
\hline $\begin{array}{l}\text { Heard of } \\
\text { malaria }\end{array}$ & 100.0 & 100.0 & 100.0 & 95.7 & 97.8 \\
\hline \multicolumn{6}{|c|}{ Symptoms of malaria } \\
\hline Fever & 100.0 & 100.0 & 100.0 & 92.5 & 93.5 \\
\hline Chill & 100.0 & 100.0 & 100.0 & 84.4 & 86.4 \\
\hline Sweating & 100.0 & 100.0 & 75.0 & 50.6 & 56.0 \\
\hline Vomiting & 100.0 & 100.0 & 100.0 & 54.4 & 60.3 \\
\hline Headache & 100.0 & 100.0 & 62.5 & 75.6 & 77.2 \\
\hline Body pain & 100.0 & 100.0 & 100.0 & 26.3 & 35.9 \\
\hline Do not know & 0.0 & 0.0 & 0.0 & 7.5 & 6.5 \\
\hline \multicolumn{6}{|c|}{ Sesonal risk of highest malaria prevelance } \\
\hline Winter & 12.5 & 25.0 & 25.0 & 13.1 & 14.1 \\
\hline Summer & 0.0 & 0.0 & 12.5 & 5.6 & 5.4 \\
\hline Rainy & 87.5 & 75.0 & 62.5 & 81.3 & 80.4 \\
\hline \multicolumn{6}{|c|}{ Transmission of malaria } \\
\hline $\begin{array}{l}\text { The bite of } \\
\text { infected } \\
\text { mosquito }\end{array}$ & 100.0 & 100.0 & 87.5 & 82.5 & 84.2 \\
\hline $\begin{array}{l}\text { Drinking } \\
\text { contaminated } \\
\text { water }\end{array}$ & 0.0 & 0.0 & 12.5 & 2.5 & 2.7 \\
\hline $\begin{array}{l}\text { Eating } \\
\text { contaminated } \\
\text { food }\end{array}$ & 0.0 & 0.0 & 0.0 & 1.3 & 1.1 \\
\hline $\begin{array}{l}\text { Close contact } \\
\text { with malaria } \\
\text { patient }\end{array}$ & 0.0 & 0.0 & 0.0 & 7.5 & 6.5 \\
\hline Do not know & 0.0 & 0.0 & 0.0 & 6.3 & 5.4 \\
\hline \multicolumn{6}{|c|}{ Biting time of mosquitoes that transmit malaria } \\
\hline Day time & 0.0 & 0.0 & 12.5 & 3.1 & 3.3 \\
\hline Night time & 100.0 & 100.0 & 75.0 & 92.5 & 92.4 \\
\hline $\begin{array}{l}\text { Both day time } \\
\text { and night } \\
\text { time }\end{array}$ & 0.0 & 0.0 & 12.5 & 4.4 & 4.3 \\
\hline Do not know & 0.0 & 0.0 & 0.0 & 0.0 & 0.0 \\
\hline \multicolumn{6}{|c|}{ Resting place of mosquitoes } \\
\hline $\begin{array}{l}\text { Dark corners } \\
\text { in the house }\end{array}$ & 100.0 & 100.0 & 100.0 & 90.0 & 91.3 \\
\hline $\begin{array}{l}\text { Domestic } \\
\text { animal } \\
\text { shelters }\end{array}$ & 100.0 & 100.0 & 100.0 & 85.0 & 87.0 \\
\hline Bushes & 12.5 & 12.5 & 25.0 & 71.9 & 64.7 \\
\hline $\begin{array}{l}\text { Tropical } \\
\text { forests }\end{array}$ & 0.0 & 12.5 & 0.0 & 31.9 & 28.3 \\
\hline $\begin{array}{l}\text { Pond or lake/ } \\
\text { Stagnant } \\
\text { water }\end{array}$ & 0.0 & 12.5 & 12.5 & 17.5 & 16.3 \\
\hline Do not know & 0.0 & 0.0 & 0.0 & 8.8 & 7.6 \\
\hline \multicolumn{6}{|c|}{ Breeding sites of mosquitoes } \\
\hline $\begin{array}{l}\text { Pond or } \\
\text { canal/ } \\
\text { Stagnant } \\
\text { water }\end{array}$ & 100.0 & 100.0 & 100.0 & 94.4 & 95.1 \\
\hline Bushes/grass & 0.0 & 12.5 & 0.0 & 22.5 & 20.1 \\
\hline $\begin{array}{l}\text { Dry and clean } \\
\text { place }\end{array}$ & 0.0 & 0.0 & 0.0 & 8.1 & 7.1 \\
\hline Do not know & 0.0 & 0.0 & 0.0 & 5.6 & 4.9 \\
\hline \multicolumn{6}{|c|}{ Malaria prevention practices } \\
\hline $\begin{array}{l}\text { Clean dark } \\
\text { corner of the } \\
\text { house }\end{array}$ & 50.0 & 62.5 & 37.5 & 30.0 & 32.6 \\
\hline $\begin{array}{l}\text { Clean bushes } \\
\text { around the } \\
\text { house }\end{array}$ & 37.5 & 37.5 & 37.5 & 16.9 & 19.6 \\
\hline $\begin{array}{l}\text { Stagnant } \\
\text { water } \\
\text { removal near } \\
\text { house }\end{array}$ & 25.0 & 62.5 & 50.0 & 33.1 & 34.8 \\
\hline
\end{tabular}

Table 7 (continued)

\begin{tabular}{|c|c|c|c|c|c|}
\hline \multirow[t]{2}{*}{ Parameters } & \multicolumn{5}{|c|}{ Respondents interviewed } \\
\hline & $\begin{array}{l}\text { Sahiyya }{ }^{\mathrm{a}} \\
\%(\mathrm{~N}=8)\end{array}$ & $\begin{array}{l}\text { MPHW } \\
\%(\mathrm{~N}= \\
8)\end{array}$ & $\begin{array}{l}\text { Village } \\
\text { leaders } \\
\%(\mathrm{~N}= \\
8)\end{array}$ & $\begin{array}{l}\text { Individuals }^{c} \\
\%(\mathrm{~N}=160)\end{array}$ & $\begin{array}{l}\text { Total } \\
\%(\mathrm{~N} \\
= \\
184)\end{array}$ \\
\hline $\begin{array}{l}\text { Use } \\
\text { insecticide- } \\
\text { treated bed } \\
\text { nets }\end{array}$ & 62.5 & 62.5 & 50.0 & 23.8 & 28.3 \\
\hline $\begin{array}{l}\text { Indoor } \\
\text { residual spray } \\
\text { (IRS) }\end{array}$ & 75.0 & 62.5 & 50.0 & 28.8 & 33.2 \\
\hline $\begin{array}{l}\text { Use mosquito } \\
\text { repellent/coil }\end{array}$ & 25.0 & 50.0 & 62.5 & 31.9 & 33.7 \\
\hline $\begin{array}{l}\text { Wear long } \\
\text { sleeve } \\
\text { clothing }\end{array}$ & 12.5 & 25.0 & 12.5 & 25.0 & 23.9 \\
\hline Do not know & 0.0 & 0.0 & 0.0 & 9.4 & 8.2 \\
\hline
\end{tabular}

a ASHA locally called 'Sahiyya'.

b Multi Purpose Health Worker (Male).

c Individual household respondents.

microorganism (acts as a larval food) that has developed in the stagnation of water storage on the outskirts of the riverbed or long-term accumulation of water. Prevalence of An. culicifacies, An. annularis, and An. fluviatilis in the eight forest-fringed tribal villages is associated with long-term water bodies created during the monsoon season, various pools developed in the riverbed, and several small streams covered in the shade of dense deep forest were suitable for breeding these species. These conditions are quite suitable for breeding and survival of An. culicifacies, An. annularis and An. fluviatilis has been confirmed by Singh et al. and Sharma et al. in the earlier studies. ${ }^{29,30}$ The highest collection of adult Anopheline species was made from cattle sheds $(57.3 \%)$ than from human dwellings (42.7\%). An. culicifacies had the highest adult density (19.2) compared to the other Anopheline species were collected from the eight villages, suggesting that the species is zoophilic in nature. An. culicifacies is the dominant species in the study area (39.9\%). The finding of our study is similar to those reported in the neighboring states of Odisha. ${ }^{31}$ An. culicifacies, An. annularis, An. fluviatilis and $A n$. minimus were the major vectors of malaria in these provinces in this study. This finding is confirmed in earlier studies in the neighboring states of Bihar, Odisha and Chattisgarh. ${ }^{24,31,32}$ During the past few years, An. vagus has reported largely and incriminated as a vector of malaria in India and neighboring country Bangladesh. ${ }^{33,34}$ Limitation of our study was that the vector incrimination was not carried out and, therefore, it was difficult to understand the role of An. splendidus, An. theobaldi, An. maculatus, An. minimus, An. vagus, An. subpictus and $A n$. barbirostris in malaria transmission in eight forest-fringed tribal villages.

In this study, the WHO-based insecticide susceptibility tests were performed on field-collected malaria vectors, including An. culicifacies, An. annularis and An. fluviatilis species, to evaluate their resistance status to DDT (4.0\%), Malathion (5.0\%) and Deltamethrin (0.05\%). Our results are in line with those of other studies carried out in Tamil Nadu, Gujarat, Madhya Pradesh, Assam-Meghalaya border and Odisha that An. culicifacies and An. annularis were resistant to DDT but were susceptible to malathion and deltamethrin.35-39 However, during the current study, An. fluviatailis was susceptible to DDT, malathion, and deltamethrin, confirming the susceptibility status of earlier studies undertaken in the Odisha neighborhood state. ${ }^{39-42}$

This is the first and foremost interviewer-administered survey was undertaken using a structured questionnaire on malaria knowledge, attitudes, and practices in these eight forest-fringed tribal villages in and around the AF region, Singharsi in the Pakur district of Jharkhand, India. The highest proportions of respondents were from age groups $31-40$ years of age and the maximum numbers of respondents were 
Table 8

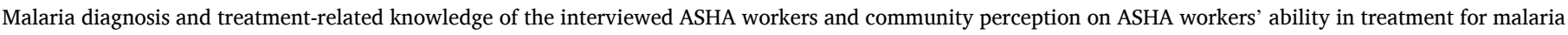
and relief in the eight villages in and around AF unit, Singharsi of the Pakur district, Jharkhand.

\begin{tabular}{|c|c|c|c|c|c|c|c|c|c|}
\hline \multirow[t]{3}{*}{ Village } & \multirow{2}{*}{\multicolumn{4}{|c|}{$\frac{\text { Operational activities by ASHA worker }}{\text { Number of ASHA worker }}$}} & \multirow{2}{*}{\multicolumn{2}{|c|}{$\begin{array}{l}\text { Availbility of stocks } \\
\text { (RDT \& anti-malarial } \\
\text { drugs) with ASHA } \\
\text { worker }\end{array}$}} & \multicolumn{3}{|c|}{ Community perception of ASHA workers' malaria-treatment and relief } \\
\hline & & & & & & & \multirow[t]{2}{*}{$\begin{array}{l}\text { Individual household } \\
\text { respondents }\end{array}$} & \multirow[t]{2}{*}{$\begin{array}{l}\text { Visited ASHA for } \\
\text { malaria } \\
\text { treatment }\end{array}$} & \multirow[t]{2}{*}{$\begin{array}{l}\text { Satisfaction on } \\
\text { malaria } \\
\text { treatment }\end{array}$} \\
\hline & Available & Trained & $\begin{array}{l}\text { With } \\
\text { RDT }\end{array}$ & $\begin{array}{l}\text { With anti-malarial } \\
\text { drugs }\end{array}$ & $\mathrm{RDT}$ & $\begin{array}{l}\text { Anti-malarial } \\
\text { drugs }\end{array}$ & & & \\
\hline Rakha & 1 & 1 & 1 & 0 & NA & NA & 21 & $6(28.6)$ & $1(4.8)$ \\
\hline Paktadi & 1 & 1 & 1 & 1 & A & NA & 21 & $12(57.1)$ & $5(23.8)$ \\
\hline Balmi & 1 & 0 & 0 & 0 & NA & NA & 21 & $3(14.3)$ & $0(0.0)$ \\
\hline Madgama & 1 & 1 & 1 & 1 & A & NA & 21 & $14(66.7)$ & $4(19.0)$ \\
\hline Mamamod & 1 & 0 & 0 & 0 & NA & NA & 21 & $4(19.0)$ & $0(0.0)$ \\
\hline Singharsi & 1 & 1 & 1 & 1 & A & A & 21 & 18 (85.7) & $14(66.7)$ \\
\hline DumDum & 1 & 1 & 1 & 0 & NA & NA & 21 & $5(23.8)$ & $1(4.8)$ \\
\hline Chabli & 1 & 1 & 1 & 1 & A & NA & 21 & $9(42.9)$ & $3(14.3)$ \\
\hline Total & 8 & 5 & 5 & 4 & 4 & 1 & 168 & $71(42.3)$ & $28(16.7)$ \\
\hline
\end{tabular}

$\mathrm{NA}=$ Not available, $\mathrm{A}=$ Available.

agriculturists. The findings of our study revealed that most of the respondents $(97.8 \%)$ were aware of malaria. Fever was proclaimed to be the most common symptom of the disease known to respondents, followed by chills, fever, diarrhea, nausea, and body pain. These findings are consistent with other studies undertaken in India and the neighboring countries of Nepal and Iran. ${ }^{43-45}$ As for malaria transmission, almost $80.4 \%$ of respondents were aware that the highest risk of malaria occurred during the rainy season and $86 \%$ of respondents were aware of the right correlation between malaria and mosquito biting, which is congruent with those studies conducted in India and Tanzania. ${ }^{46,47}$ Knowledge regarding mosquito breeding and resting places was high among the study community, consistent with the results of some other studies conducted in India and Botswana. ${ }^{48,49}$ Approximately $92.4 \%$ of respondents stated that night time was the biting time of malaria-borne mosquitoes, and the findings were concurring with other studies conducted in India and Swaziland. ${ }^{50,51}$ In comparison to other studies undertaken in India and Mexico, a lower proportion of respondents in our study have taken precautionary measures against malaria. ${ }^{51-53}$

ASHA, recognized as a community health working personal, plays a key role in providing health services at the village level. Malaria monitoring and therapy utilizing ASHA workers may be expected to reduce the burden of malaria in tropical tribal areas with poor communication facilities. Our study showed that $62.5 \%$ of ASHA workers were trained in malaria diagnosis and about $50 \%$ of ASHA workers were trained in malaria treatment. We found that RDT kits were available to ASHA workers in four villages, but anti-malaria drugs were available to one ASHA worker, which resulted in a very low proportion (16.7\%) of households being satisfied with ASHA's malaria treatment service. The results were consistent with other studies undertaken in the nearby states of Odisha and Chhattisgarh in India. ${ }^{54,55}$

\section{Conclusion}

The survey provided important insights into tribal malaria. The prospective study showed that the study area had a high incidence of malaria and P. falciparum infection was the most dominant of Plasmodium infections. The infection of mixed-species with $P$. falciparum and $P$. vivax is not uncommon in these provinces. The infection of mixedspecies may be complicated by severe malaria. An. culicifacies were the most dominant species of the circulated anophelines in these provinces. An. culicifacies, An. annularis, An. fluviatilis and An. minimus were the major vectors of malaria; furthermore, considering the topography and climatic environment, it is presumed that the high density of anophelines that influence the malaria situation in these provinces. The susceptibility status of the insecticide reveals that An. culicifacies, An. annularis and An. fluviatilis was sensitive to malathion (5\%) and deltamethrin $(0.05 \%)$ which would be useful and helpful for indoor residual spraying (IRS) in the control of parasitic load in the community. This study found that most villagers, including health workers, had excellent knowledge of malaria, but did not adopt effective prevention measures as observed by the authors. Traditional therapies and native remedies are followed by the tribal community, as the early detection of malaria and its early treatment (EDPT) approach has failed at the village level in these provinces because of unskilled ASHA workers in the diagnosis and treatment of malaria cases, and also lack logistical support with ASHA workers, including RDT kits and antimalarial drugs. Poor socioeconomic conditions, inaccessible communication, poor sanitation, deficient in preventive practices, high vector density, presence of the parasite load and lack of EDPT and vector control strategy in the community have indicated that the population living in these eight forestfringed villages is more vulnerable to malaria.

It was, therefore, suggested that the implementation of the EDPT facilities at the village level, the distribution and promotion of longlasting insecticide-treated nets (LLIN), and community involvement in malaria intervention strategies be prioritized. In addition, systematic monitoring of environmental risk factors, vector prevalence, disease surveillance, and insecticide susceptibility bioassays for mosquito vectors at the village level at regular intervals is required to confirm the true burden of malaria, the operational activities of control strategies and select an effective insecticide for vector control interventions. This would help in planning and evidence-based preventive practices to reduce malaria, including morbidity and mortality among the Sauria Paharia, a primitive and vulnerable tribal group (PTG) in the region.

\section{Ethical approval}

This was a one time fever survey/investigation conducted on the request of Air Force and the survey was approved by the Director, NIMR, Delhi.

\section{Authors' contributions}

This study was designed by M K D. M K D and M.R.K.R have carried out the field and laboratory experiment. M.R.K.R has performed the statistical analysis. M.R.K.R has written the manuscript. MKD has corrected the final manuscript. The authors have read and approved the final manuscript.

\section{Declaration of competing interest}

The authors declare that they have no competing interests. 


\section{Acknowledgments}

The authors are thankful to the population in the study area of Ranchi district of Jharkhand, for their cooperation and also grate full to The Director, ICMR-National Institute of Malaria Research, New Delhi and The State Health Department of Jharkhand for their support.

\section{References}

1 Kumar A, Valecha N, Jain T, Dash AP. Burden of malaria in India: retrospective and prospective view. Am J Trop Med Hyg. 2007;77(6-Suppl):69-78. https://doi.org/ 10.4269/ajtmh.2007.77.69.

2 Anonymous. Malaria situation. National vector borne disease control programme. Available at: http://nvbdcp.gov.in/Doc/mal_situation_Jan2015.pdf; 2015.

3 Dev V, Sharma VP. The dominant mosquito vectors of human malaria in India. In: Sylvie Manguin, ed. Anopheles Mosquitoes - New Insights into Malaria Vectors. InTech; 2013:239-271. https://doi.org/10.5772/3392.

4 Rao MRK, Padhy RN, Das MK. Episodes of the epidemiological factors correlated with prevailing viral infections with dengue virus and molecular characterization of serotypespecific dengue virus circulation in eastern India. Infect Genet Evol. 2018;58: 40-49. https://doi.org/10.1016/j.meegid.2017.12.005.

5 Panda M, Mohapatra A. Malaria control - an over view in India. J Hum Ecol. 2004;15 (2):101-104. https://doi.org/10.1080/09709274.2004.11905673.

6 Singh N, Singh OP, Sharma VP. Dynamics of malaria transmission in forested and deforested region of mandla district, Central India, Madhya Pradesh. J Am Mosq Contr Assoc. 1996;12:225-234. https://doi.org/10.1371/journal.pone.0073730.

7 Anonymous. Annual report of the economic devolpment of STs. Available at: http ://www.ncst.nic.in/sites/default/files/documents/central_government/File415.pdf.

8 Anonymous. Report of the Tribal Empowerment and Livelihood Project. Jharkhand, India: International Fund for Agricultural Development; 2014. Available at: htt ps://operations.ifad.org/documents/654016/21c69e6e-15d6-4116-a07c-4440 dd2c5ce2.

9 Anonymous. Report of the Scheme for Development of Particularly Vulnerable Tribal Groups (PVTGS). Ministry of Tribal Affairs, Govt. of India; 2015. Available at https:// tribal.nic.in/writereaddata/Schemes/4-5NGORevisedScheme.pdf.

10 Anonymous. Annual Report of the Malaria Control Programme Annual Report, Pakur District, Jharkhand of NVBDCP, National Vector Borne Disease Control Programme; 2014. Available at: http://www.nvbdcp.gov.in/home.html.

11 Das NG, Baruah I, Kamal S, Sarkar PK, Das SC, Santhanam K. An epidemiological and entomological investigation on malaria outbreak at Tamulpur PHC, Assam. Indian J Malariol. 1997;34:164-170.

12 Anonymous. National drug policy on malaria-2013 of the directorate of NVBDCP, National vector borne disease control programme. Available at: http://www.http:// nvbdcp.gov.in/Doc/National-Drug-Policy-2013.pdf; 2013.

13 Das BP, Rajgopal R, Akiyama J. Pictorial key to the species of Indian Anopheline mosquitoes. J Pure Appl Zool. 1990;2(3):131-162.

14 Nagpal BN, Srivastava A, Saxena R, Ansari MA, Dash AP, Das SC. Pictorial Identification Key for Indian Anophelines. Delhi: Malaria Research Centre (ICMR); 2005.

15 Anonymous. Test Procedures for Insecticide Resistance Monitoring in Malaria Vector Mosquitoes. World Health Organization; 2013.

16 Anonymous. Discriminating Concentrations of Insecticides for Adult Mosquitoes. World Health Organization; 2012.

17 Christopher SR. The Fauna of British India, Including Ceylon and Burmavol. 4. London: Taylor and Francis; 1933:371.

18 Barraud PJ. The faunaof British India, including Ceylon and Burma. In: Diptera. Family Culieldae. Tribes Megarhinini and Culicini. London: Taylor and Francis; 1934: 463; vol. 5.

19 Puri IM. Synaptic table for the identification of the anopheline mosquitoes of India, Hlth. Bull No. 1955;10, ivth ed.

20 Wattal BL, Karla NL. Region wise pictorial keys to the female Indian Anophelese. Bull Nalt. Soc. Ind. Mal. Mosq. Dis. 1961;9:85-138.

21 Nagpal BN, Sharma VP. Indian Anophelines. New Hampshire. Science Publishers Inc.; 1995.

22 Rajpramukh KE. Tribal Health in Eastern Ghat. New Delhi: Concept Publication Company; 2012, 1.

23 Singh N, Chand SK, Bharti PK, et al. Dynamics of forest malaria transmission in Balaghat district, Madhya Pradesh, India. PLoS One. 2013;8(9), e73730. https://doi. org/10.1371/journal.pone.0073730.

24 Das NG, Bhuyan M, Das SC. Entomological and epidemiological studies on malaria in Rajmahal Range, Bihar. Indian J Malariol. 2000;37:88-96.

25 Dutta P, Bhattacharyya DR. Malaria survey in some parts of Namsang Circle of Tirap district, Arunachal Pradesh. J Comm Dis. 1990;22:92-97.

26 Das NG, Talukdar PK, Das SC. Epidemiological and entomological aspects of malaria in forst fringed villages of Sonitpur district, Assam. J Vector Borne Dis. 2004:5-9.

27 Sharma SK, Tyagi PK, Padhan K, et al. Epidemiology of malaria transmission in forest and plain ecotype villages in Sundargarh District, Orissa, India. Trans R Soc Trop Med Hyg. 2006;100(10):917-925. https://doi.org/10.1016/j.trstmh.2006.01.007.

28 Rajagopalan PK, Das PK, Pani SP, et al. Parasitological aspects of malaria persistence in Koraput district Orissa, India. Indian J Med Res. 1990;91:44-51.

29 Singh N, Singh OP, Soan V. Mosquito breeding in rice fields and its role in malaria transmission in Mandla district, M.P. Indian J Malariol. 1989;26(4):191-198.
30 Sharma VP, Prasittisuk C, Kondrashin AV. Magnitude of forest related malaria in the WHO, Southeast Asia region. Forest malaria in South-east Asia. In: Sharma VP, Kondrashin AV, eds. Proceedings of an Informal Consultative Meeting. Delhi: Malaria Research centre; 1991:29-53.

31 Das M, Das B, Patra AP, et al. Anopheles culicifacies sibling species in Odisha, eastern India: first appearance of An. culicifacies $\mathrm{E}$ and its vectorial role in malaria transmission. Trop Med Int Health. 2013;18:810-821. https://doi.org/10.1111/ tmi.12112.

32 Nanda N, Bhatt RM, Sharma SN, et al. Prevalence and incrimination of An. fluviatilis species S (Diptera: Culicidae) in a malaria endemic forest area of Chhattisgarh state, central India. Parasites Vectors. 2012;5:215-220. https://doi.org/10.1186/17563305-5-215.

33 Alam MS, Khan MGM, Chaudhury N, et al. Prevalence of anopheline species and their Plasmodium infection status in epidemic-prone border areas of Bangladesh. Malar J. 2010;9:15. https://doi.org/10.1186/1475-2875-9-15.

34 Prakash A, Bhattacharyya DR, Mohapatra PK, Mahanta J. Role of the prevalent Anopheles species in the transmission of Plasmodium falciparum and P. vivax in Assam state, north-eastern India. Ann Trop Med Parasitol. 2004;98(6):559-568. https://doi. org $/ 10.1179 / 000349804225021361$.

35 Mittal PK, Adak T, Singh OP, Raghavendra K, Subbarao SK. Reduced susceptibility to deltamethrin in Anopheles culicifacies sensu lato in District Ramanathapuram in Tamil Nadu: selection of a pyrethroid resistant strain. Curr Sci. 2002;82:185-188.

36 Singh OP, Raghavendra K, Nanda N, Mittal PK, Subbarao SK. Pyrethroid resistance in Anopheles culicifacies in Surat district of Gujarat, west India. Curr Sci. 2002;82: 547-550.

37 Mishra AK, Chand SK, Barik TK, Dua VK, Raghavendra K. Insecticide resistance status in Anopheles culicifacies in Madhya Pradesh, central India. J Vector Borne Dis. 2012;49 (1):39-41. pmid:22585243.

38 Dhiman S, Rabha B, Goswami B, et al. Insecticide resistance and human blood meal preference of Anopheles annularis in Assam Meghalaya border, Northeast India. J Vector Borne Dis. 2014;51:133-136.

39 Sharma SK, Upadhyay AK, Haque MA, Singh OP, Adak T, Subbarao SK. Insecticide susceptibility status of malaria vectors in some hyper-endemic tribal districts of Odisha. Curr Sci. 2004;87(12):1722-1726.

40 Sahu SS, Gunasekaran K, Jambulingam P, Das PK. Susceptibility status of An. fluviatilis, An. annularis and An. culicifacies to insecticides in Koraput district, Orissa. Indian J Malariol. 1990;27:51-53. PMID: 2384186.

41 Chand SK, Yadav RS. Insecticide susceptibility of mosquito vectors in Sundargarh district, Odisha. Indian J Malariol. 1991;28:65-68. PMID: 1915985.

42 Sahu SS, Patra KP. A study on insecticides resistance in An. fluviatilis and An. culicifacies to HCH and DDT in Malkangiri district of Orissa. Indian J Malariol. 1995; 32(3):112-118. PMID: 8936293.

43 Madne G, Jindal AK, Patel BB, Sharma R, Kant R. Knowledge and practices concerning malaria in rural community of Pune district. Med J DY Patil Univ. 2014;7: 450-453. https://doi.org/10.4103/0975-2870.135261.

44 Joshi AB, Banjara MR. Malaria related knowledge, practices and behaviour of people in Nepal. J Vector Borne Dis. 2008;45:44-50. PMID: 18399316.

45 Hanafi-Bojd AA, Vatandoost H, Oshaghi MA, et al. Knowledge, attitudes and practices regarding malaria control in an endemic area of Southern Iran. Southeast Asian J Trop Med Publ Health. 2011;42:491-501. PMID: 21706926.

46 Yadav SP, Yadav S, Kuma P. Knowledge, treatment-seeking behaviour and socioeconomic impact of malaria in the desert of Rajasthan, India. South African J Infect Dis. 2013;28(1):41-47. https://doi.org/10.1080/10158782.2013.11441518.

47 Mathania MM, Kimera SI, Silayo RS. Knowledge and awareness of malaria and mosquito biting behaviour in selected sites within Morogoro and Dodoma regions Tanzania. Malar J. 2016;15:287. https://doi.org/10.1186/s12936-016-1332-4.

48 Singh RK, Haq S, Dhiman RC. Studies on knowledge, attitude and practices in malaria endemic tribal areas of Bihar and Jharkhand, India. J Trop Dis. 2013;1:110. https://doi.org/10.4172/2329-891X.1000110.

49 Chirebuv E, Chimbari MJ, Ngwenya BN. Knowledge and practices on malaria in Tubu village, in a malaria endemic area in Northern Botswana; implications for interventions. Malaria World J. 2013;4(15):1-9.

50 Hlongwana KW, Mabaso ML, Kunene S, Govender D, Maharaj R. Community knowledge, attitudes and practices (KAP) on malaria in Swaziland: a country earmarked for malaria elimination. Malar J. 2009;8:29. https://doi.org/10.1186/ 1475-2875-8-29.

51 Vijayakumar KN, Gunasekaran K, Sahu SS, Jambulingam P. Knowledge, attitude and practice on malaria: a study in a tribal belt of Orissa state, India with reference to use of long lasting treated mosquito nets. Acta Trop. 2009;112(2):137-142. https://doi. org/10.1016/j.actatropica.2009.07.011.

52 Kishore J, Gupta VK, Singh SV, Garg S, Kaur R, Ingle GK. Impact of health education intervention on knowledge and community action for malaria control in Delhi. J Comm Dis. 2008;40(3):183-192. PMID: 19245156.

53 Rodríguez AD, Penilla RP, Henry-Rodríguez M, Hemingway J, Francisco BA, Hernandez-Avila JE. Knowledge and beliefs about malaria transmission and practices for vector control in southern Mexico. Salud Publica Mex. 2003;45:110-116.

54 Sahu SS, Rao SP, Dash S. Performance of accredited social health activists (ASHAs) in diagnosis and treatment of malaria in eight falciparum endemic tribal districts of southern Odisha, India. J Comm Dis, 2016;48(2):12-19.

55 Chourasia MK, Raghavendra K, Bhatt RM, Swain DK, Dutta GDP, Kleinschmidt I. Involvement of Mitanins (female health volunteers) in active malaria surveillance, determinants and challenges in tribal populated malaria endemic villages of Chhattisgarh, India. BMC Publ Health. 2017;18:9. https://doi.org/10.1186/s12889017-4565-4. 